\title{
The Impact of Partnership between the Public Authority for Applied Education and Training and the Kuwaiti Labor Market on the Outcome Quality of the Training Sector
}

\author{
Hadi S. AlHarbi ${ }^{1}$ \\ ${ }^{1}$ Faculty Member at the Higher Institute for Administrative Services, Kuwait \\ Correspondence: Hadi S. AlHarbi, Faculty Member at the Higher Institute for Administrative Services, Kuwait. \\ E-mail: hadialharbi@yahoo.com
}

Received: September 15, 2019

Accepted: October 20, 2019 Online Published: November 8, 2019

doi:10.5539/ijbm.v14n12p53

URL: https://doi.org/10.5539/ijbm.v14n12p53

\begin{abstract}
The present study aimed to explore the impact of partnership between the Public Authority for Applied Education and Training and the Kuwaiti labor market on the outcome quality of the training sector. The study's population consists from all the officials who work at the public bodies that benefit from the outcomes of the Public Authority for Applied Education and Training. A simple random sample was selected. It consists from 300 officials. Questionnaire forms were distributed to all of the selected officials. However, 209 forms only were retrieved and considered valid for statistical analysis. Thus, the response rate is $69.7 \%$.

It was found that the partnership between the Public Authority for Applied Education and Training and the Kuwaiti labor market has a significant impact on the outcome quality of the training sector. The researcher recommends activating the role of the partnership between the Public Authority for Applied Education and Training and the Kuwaiti labor market.
\end{abstract}

Keywords: training, training needs, employee performance, public authority for applied education and training

\section{Introduction}

Today, people have been witnessing many changes. For instance, they have been witnessing many political, economic and social changes. They have been also witnessing many developments in the field of knowledge. In the light of the aforementioned, private and public organizations have been providing much attention to the development of their capabilities. Such attention has been provided to keep up with the changes. Therefore, organizations have been providing much attention to training as a key element for achieving development.

In the light of the aforementioned, organizations must perceive training as an investment that shall generate profits. In other words, they shouldn't perceive training as something costly. That is because training plays an important role in providing public organizations with more revenues. It's because training plays an important role in developing human resources. It should be noted that developing HR is something essential. That's because such development shall raise the employees' productivity and the organizational performance levels.

Training is a planned process. It's carried out by trainers through using various methods. It's carried out in the aim of improving employees' capabilities, skills, efficiency and performance. It participates in developing employees' team work skills. That's done through educating employees. In addition, training participates in raising the organizational efficiency level. It participates in meeting the organizational goals. It should be noted that education and development are activities carried out by the human resources management. Through practicing these activities, the development needs of employees - in various administrative levels - shall be identified and met. That shall be done based on the employees' weaknesses in behavior and performance (Al-Janabi, 2009).

A partnership has been existing for more than 30 years between the Public Authority for Applied Education and Training and the Kuwaiti labor public market. For instance, the latter authority developed diploma programs for training the ones who finish the secondary school stage. The latter programs take about two years. They are developed for meeting the demands of the public marketplace. The trainees enrolled in the latter programs are provided with job opportunities when they finish their training. The latter programs involve several workshops 
that are held in collaboration with the labor market. They provide trainees with all the skills and knowledge that are needed for holding a job. These programs include practical and field training in collaboration with the labor market. Thus, when the trainee finishes his training, he shall head straight to his intended workplace. In the light of the aforementioned, the present study aimed to explore the impact of partnership between the Public Authority for Applied Education and Training and the Kuwaiti labor market on the outcome quality of the training sector.

\subsection{The Study's Significance}

The significance of the present study arises from the significance of training employees. For instance, several studies found out that training can significantly increase employees' performance level. Such studies include the ones conducted by: Lawson \& Alan (2004). In addition, the significance of the present study arises from the significance of the study's subject. For instance, training is considered one of the primary pillars of the comprehensive development process.

It should be noted that training is considered very significance in Kuwaiti organizations. The latter organizations have been providing much attention to training. For instance, they have been providing much attention to the investment in human capital. Such attention has been provided in order to improve employees' skills and knowledge and raise their efficiency level. To be more specific, the significance of the present study arises from the following:

1. The present study sheds a light on training which is an effective tool for developing employees. Training plays an effective role in enabling employees to carry out work tasks effectively and efficiently. That shall ensure saving the costs associated with failure. It shall improve the employees' morale.

2. The present study provides recommendations that participate in activating the role of the partnership between the Public Authority for Applied Education and Training and the Kuwaiti labor market

\subsection{Statement of the Problem}

There aren't many studies that aim to explore the impact of partnership between the Public Authority for Applied Education and Training and the Kuwaiti labor market on the outcome quality of the training sector. Therefore, the problem of the present study is represented in the following questions:

1. What's impact of the process of identifying the training needs on the trainees' performance in Kuwait?

2. What's impact of the process of designing the training programs and diploma training programs on the trainees' performance in Kuwait?

3. What's impact of the process of implementing the training programs and diploma training programs on the trainees' performance in Kuwait?

4. What's impact of the process of selecting the trainees on the trainees' performance in Kuwait?

5. What's impact of the process of selecting the trainers on the trainees' performance in Kuwait?

6. What's impact of the process of evaluating the training programs on the trainees' performance in Kuwait?

1.3 The Study's Model

The independent variable

The dependent variable

- Identifying the training needs

- Designing the training programs and the diploma training programs

- Implementing the training programs and the diploma training programs

- Selection of trainees

- Selection of trainers

- Assessing the training programs

Figure 1. The study's model

Source: Young (2009); Wright \& Geroy (2010); Swart et al., (2005); Nassazi (2013). 


\subsection{The Study's Hypotheses}

The following study's hypotheses were developed based on the study's objectives:

Ha.1) - The partnership between the Public Authority for Applied Education and Training and the Kuwaiti labor market has an impact on the outcome quality of the training sector in Kuwait.

Ha.2) - The process of identifying the training needs has an impact on the trainees' performance in Kuwait.

Ha.3) - The process of designing the training programs and diploma training programs has an impact on the trainees' performance in Kuwait.

Ha.4)- The process of implementing the training programs and diploma training programs has an impact on the trainees' performance in Kuwait.

Ha.5)-The process of selecting the trainees has an impact on the trainees' performance in Kuwait.

Ha.6)- The process of selecting the trainers has an impact on the trainees' performance in Kuwait.

Ha.7)- The process of evaluating the training programs has an impact on the trainees' performance in Kuwait.

\section{The Study's Theoretical Framework}

Gomez et al. (2001, p. 260) suggests that training is the process of providing people with skills that enable them to eliminate the shortcomings in their performance. White \& Mackenzie-Davey (2003, p.228) suggest that training is a process that aims at making changes in the organization and turn it into a learning organization. They suggest that training enables the organization to assess and develop its employees. Training may be defined as an organized effort that is exerted in the aim of developing people's capabilities and changing their behavior. It shall enable the organization to meet its goals.

Based on the definitions of training, the following can be concluded:

- Training is a human activity

- Training is a planned activity that is performed for meeting specific goals

- Training is provided to make changes in specific areas

- Training is an organized process that aims at developing people's capabilities and potentials. That shall participate in meeting the intended goals of the organization.

In the light of the aforementioned, the researcher of the present study believes that training is a management function. He also believes that the training process must be provided to employees in every organization regardless of its activities. He believes that training enable employees to keep up with the developments in all areas. He believes that training participates in developing employees regardless of their positions, or functions. He believes that training participates in improving employees' productivity. He also believes that the training process must be provided to all employees without excluding anyone.

\subsection{Identifying the Training Needs}

Training needs refer to a group of things that must be changed or added to the cognitive, emotive, or behavioral aspects of the employees' personality. It enables the organization to avoid the things that may hinder its processes. It enables the organization to avoid the things that may hinder the implementation of its general policy. It enables organization to avoid the things that may hinder the process of meeting the organizational goals.

In other words, the training needs are represented in the gap existing between the knowledge, and skills that are actually possessed by the employee and the ones that should be possessed by him. When identifying the extent of the latter gap, the type of training that should be provided to employees can be identified.

The training needs can be represented in the extent of the gap existing between the performance level that is achieved by employees and the performance level that must be achieved by them. In other words, the training needs can be represented in the extent of the gap existing between the work requirements that have been met by employees and the ones that should be met. Such requirements are represented in skills and knowledge (Jacqueline \& Maria, 2006, p. 395).

After identifying the extent of the training gap, another stage must start. It's represented in the processing stage. Through the latter stage, the training level shall be determined to fill the gap between the employee's actual performance and the intended one. The training levels are:

1. Preliminary training: It's the initial level of training. It aims to raise the trainees' awareness about a significant topic or issue. 
2. Operational training: It's provided to raise the trainees' performance level. It involves two types of training. The first one targets the trainees who do not have adequate amount of knowledge, and skills. The second one targets the trainees who have adequate amount of knowledge, and skills.

3. Practical training: It aims to improve the employee's capabilities. In this training, the employee is provided with an environment that simulates his actual workplace environment (Redwan, 2012).

\subsection{Choosing the Training Content}

After setting the training goals, the training content must be selected. Through the latter process, the targeted areas shall be selected. The latter process aims to translate the training goals into real outcomes (Abed Al-Fattah, 2013).

\subsection{The Employee Performance}

The employee is considered one of the important organizational assets. That is because the employee who shows a high performance shall participate in raising the organizational performance level and vice versa (Ahmed \& Ramzan, 2013, p.65).

Guan \& Frenkel (2018, p.65) define employee performance as the extent of mastering a specific activity by an employee who can perform the latter activity due to having the required skills, and capabilities. Hermawati \& Mas (2017, p. 1151) define the employee performance as the extent of gap that exist between the intended outcomes and the actual outcomes that have been achieved by the employee. Celine (2018) defines the employee performance as the outcomes that have been achieved by the employee. He believes that it's assessed based on the quantity and quality.

\section{The Dimensions of Performance}

\section{Compliance with the behavioral standards}

It refers to showing positive behaviors at work and refraining from negative work behaviors. The positive ones include: compliance with the working hours. The negative ones include: going late to work or absence from work. Behavioral standards refer to a set of rules, and regulations which the employee must comply with during the official working hours. It should be noted that the extent of the employee's compliance with the organization's rules, and regulations is assessed by the organization. The employee's compliance with ethics is assessed too (Aldulaimi, 2016, p. 65).

Mohammad \& Quoquab (2016, p. 371) suggest that the organization's behavioral standards regulate the course of action inside the organization and the way employees deal with each other. They suggest that such standards regulate the way employees deal with the management. They suggest that such standards identify the way in which the organization deals with its acquisitions. They suggest that such standards govern the organization's communication process, working hours, and the employee's charge.

\section{The actual outcomes}

Performance can be measured through identifying the extent of the gap existing between the intended outcomes and the ones that have been actually achieved. Performance can be measured through identifying the extent of the gap existing between the intended goals - which were set by the management - and the ones that have been met by the employees (Hasu et al., 2014,p.319).

\section{Personal characteristics}

They refers to the employee's personal characteristics. Such characteristics can facilitate the way in which the employee carries out his work tasks. Such characteristics include: loyalty, belonging, and communication and leadership skills. Sanda \& Kuada $(2016$, p.520) suggest that there are several organizational factors that participate in promoting certain personal characteristics among employees For instance, the organizational factors make the customer service employees accurate. In addition, such factors make the customer service employee become nice when dealing with customers.

\subsection{Standards for Assessing the Employee Performance}

Organizations seek assessing their employees' performance in a fair manner. That can be done through collecting detailed information about the performance and achievement of employees. The employee assessment process must be based on fixed standards and foundations which must be fair. These assessment standards must be acknowledged by most companies (Nazir\& Islam, 2017, 108).

Al-Khafaji $(2016,161)$ suggests that the employee assessment standards refer to specific regulations and foundations that govern the process of assessing employees. Based on the employee assessment standards, the 
employee's achievements are assessed. That is done to identify his performance level. The employee assessment standards shall participate in promoting knowledge among employees about the tasks that must be done to meet the organization's goals. Al-Khafaji (2016) suggests that the most important performance standards are:

\section{History-based standards}

Through these standards, the organization shall assess the gap that is between the previous performance and the current one. That's done based on data, statistics, and information about a specific activity or department. Through the history-based standards, the organization can conduct a comparison between its performance during a specific year and another or during a specific season and another. In case there are shortcomings, the organization can identify them and their reasons based on the history-based standards. That shall enable the organization to find solutions for eliminating these shortcomings. The latter standards are considered the most important standards for assessing the employee's performance and compare it with the performance of other employees. These standards enable the organization to identify the employee who's qualified the most to manage a specific department of division.

\section{Competition-based performance}

In this case, the organization shall conduct a comparison between the performance of a specific department - or division - and another. It should be noted that comparing performance levels is the most useful activity in the organization. That's because the latter activity enables the organization to raise its performance. Thus, that shall enable the organization to achieve the intended outcomes.

\section{The target performance}

It refers to the performance that the organization seeks achieving. It should be noted that setting specific goals and strategies by the top management is necessary. That's because the latter process shall enable the organization to direct employees' skills, and potentials towards achieving the sought goals and performance. Thus, that shall enable the organization to avoid wasting resources and efforts.

Scott \& Duffy (2015, p.144) suggest that setting goals doesn't have any significance if employees don't have adequate knowledge about them. The latter researchers suggest that the lack of knowledge among employees about the organizational goals shall negatively affect the organization's performance. Promoting knowledge among employees about the goal shall enable the organization to save time, and utilize skills and potentials effectively.

\section{Perfection}

Perfection is achieved when the organization fully complies with a specific set of standards that are illustrated based on a specific theoretical framework. It may be difficult to comply fully with such a set. However, the extent of complying with standards shall enable the organization to identify its performance and the extent of meeting the goals.

\subsection{The Impact of Training on Employee Performance}

Several studies aimed to shed a light on the impact of training on employee performance. For instance, Wei-Tao (2006) aimed to explore the impact of self-efficacy, and training framework and motivation on the training effectiveness in British companies. He selected a sample that consists from 126 trainees. The latter trainees were enrolled in a training program about designing and implementing computer programs. All of the selected trainees are young. Their age is less than 35 years. The latter researcher aimed to assess the trainees before, after and during the training program. He found that the trainer's efficiency, training motivation and supervisors' support have a significant impact on the training effectiveness. He also found that trainees' motivation, and independency and organizational climate have a positive impact on the training effectiveness.

Marcel et al. (2002) aimed to explore the effectiveness of in-service training programs. They aimed to explore the relationship between the effectiveness of the latter training programs and their outcome quality. It was found that preparing \& planning training in-service training programs shall participate in improving these programs. It was found that self-efficacy and management support are considered the most important measures for measuring the effectiveness of in-service training programs.

Gauld and Miller (2004) found that the trainer's qualification and competency shall affect the effectiveness of training. They found that there are differences between the effectiveness of training programs which can be attributed to the trainer's gender. The latter differences are for the favor of male trainers. They found that there are differences between the effectiveness of training programs which can be attributed to the trainer's experience. The latter differences are for the favor of the trainers who have more than 10 years of experience. 
Nivorozhkin (2005) aimed to measure the effectiveness of several professional training programs in improving the expertise of the non-employed people in the Russian countryside. The latter programs are financed by the Russian government. The latter researcher selected a sample that consists from 2000 trainees who were selected randomly from the population. The population involves all the trainees who were enrolled in the latter programs. It was found that there's an improvement in the expertise of trainees after they finished training. However, the latter improvement diminished after one year.

\subsection{The Study's Methodology}

The researcher adopted a descriptive analytical methodology. That was done to identify the impact of the partnership between the Public Authority for Applied Education and Training and the Kuwaiti labor market on the outcome quality of the training sector.

\subsection{The Study's Population and Sample}

The study's population consists from all the officials who work at the public bodies that benefit from the outcomes of the Public Authority for Applied Education and Training. A simple random sample was selected. It consists from 300 officials. Questionnaire forms were distributed to all of the selected officials. However, 209 forms were retrieved and considered valid for statistical analysis. Thus, the response rate is $69.7 \%$.

\subsection{Data Collection Methods}

The researcher used two types of sources, which are:

1. Secondary sources: These sources include books, previous studies and scientific references which shed a light on the study's subject

2. Primary source: That's represented in the study's questionnaire. The questionnaire forms were distributed to the sample to collect data.

\subsection{Statistical Analysis}

The demographic characteristics of the study's sample are presented in table 1 below:

Table 1. The demographic characteristics of the study's sample

\begin{tabular}{llll}
\hline Characteristic & & Frequency & Percentage \% \\
\hline Gender & Male & 103 & 49.3 \\
& Female & 106 & 50.7 \\
Age & 30 years or less & 34 & 16.3 \\
& 31-40 years & 92 & 44.0 \\
& 41-50 years & 62 & 29.7 \\
& More than 50 years & 21 & 10.0 \\
Academic qualification & Less than a bachelor & 91 & 43.5 \\
& degree & & \\
& BA degree & 109 & 52.2 \\
& MA degree & 7 & 3.3 \\
Years of experience & PhD degree & 2 & 1.0 \\
& Five years or less & 26 & 12.4 \\
& 6-10 years & 31 & 14.8 \\
& 11-15 years & 53 & 25.4 \\
& More than 15 years & 99 & 47.4 \\
\hline
\end{tabular}

In terms of gender, it can be noticed that most of the respondents are females. For instance, $50.7 \%$ of the respondents are females and $49.3 \%$ are males.

In terms of age, it can be noticed that the age of $44 \%$ of the respondents is within the range of (31-40) years. It can be noticed that the age of $29.7 \%$ of the respondents is within the range of 41-50 years. It can be noticed that the age of $16.3 \%$ of the respondents is 30 years or less. In terms of the academic qualification, $43.5 \%$ of the respondents hold a degree that's less than the BA degree. It was found that $52.2 \%$ of the respondents hold a BA degree. In terms of the years of experience, $47.4 \%$ of the respondents have more than 15 years of experience. It was found that $25.4 \%$ of the respondents have11-15 years of experience. It was found that $14.8 \%$ of the respondents have 6-10 years of experience. It was found that $12.4 \%$ of the respondents have five years or less of 


\section{experience.}

\section{Results}

Arithmetic means and standard deviations are presented in table 2 below. They were calculated to identify the respondents' attitudes.

Table 2. The arithmetic means and standard deviations to identify the respondents' attitude

\begin{tabular}{|c|c|c|}
\hline & Arithmetic means & standard deviations \\
\hline \multicolumn{3}{|l|}{ Identifying the training needs } \\
\hline $\begin{array}{l}\text { 1. The training needs are identified based on the demands of the public labor } \\
\text { market }\end{array}$ & 3.84 & .940 \\
\hline $\begin{array}{l}\text { 2. The training needs are identified based on the job description in various } \\
\text { public sectors }\end{array}$ & 3.75 & .973 \\
\hline $\begin{array}{l}\text { 3. The training needs are identified through reviewing the opinions of } \\
\text { administrators in various administrative levels at ministries and public bodies. }\end{array}$ & 3.57 & 1.050 \\
\hline $\begin{array}{l}\text { 4. The employees' training needs are identified based on the opinions of the } \\
\text { trainers who are specialized in the relevant field }\end{array}$ & 3.76 & .961 \\
\hline $\begin{array}{l}\text { 5. The employees' training needs are identified based on tests that are held in } \\
\text { the concerned ministries }\end{array}$ & 3.56 & 1.055 \\
\hline \multicolumn{3}{|l|}{ Designing the training programs and diploma training programs } \\
\hline $\begin{array}{l}\text { 1. The training programs and diploma training programs are designed in a } \\
\text { clear manner that's consistent with the work demands at public institutions }\end{array}$ & 3.76 & .997 \\
\hline $\begin{array}{l}\text { 2. The training programs and diploma training programs are designed to } \\
\text { solve work-related problems at public institutions }\end{array}$ & 3.75 & 1.003 \\
\hline $\begin{array}{l}\text { 3. The training programs and diploma training programs are designed based } \\
\text { on the employees' training needs }\end{array}$ & 3.79 & .973 \\
\hline \multicolumn{3}{|l|}{ Implementing the training programs and diploma training programs } \\
\hline $\begin{array}{l}\text { 1. The time needed for making presentations about the public training } \\
\text { subjects shall be identified. }\end{array}$ & 3.89 & .828 \\
\hline $\begin{array}{l}\text { 2. Various methods are used for delivering information to the trainees who } \\
\text { hold a secondary school certificate }\end{array}$ & 4.03 & .958 \\
\hline $\begin{array}{l}\text { 3. Modern and advanced methods - which are consistent with the nature of } \\
\text { work at ministries - are used }\end{array}$ & 3.92 & 1.067 \\
\hline \multicolumn{3}{|l|}{ Selection of trainees } \\
\hline The trainees are selected based on the ministry's needs & 3.77 & 1.045 \\
\hline The trainees are selected based on their personal characteristics & 3.45 & 1.074 \\
\hline $\begin{array}{l}\text { 3. The ones who were enrolled in the diploma programs were selected } \\
\text { based on the personal interests and desires }\end{array}$ & 3.49 & 1.114 \\
\hline $\begin{array}{l}\text { 4. A specific policy is implemented when selecting the trainees. The latter } \\
\text { policy is consistent with the trainees' GPA in the secondary school certificate } \\
\text { Selection of trainers }\end{array}$ & 3.44 & 1.139 \\
\hline $\begin{array}{l}\text { 1. The trainers who are highly capable to run the lectures of the diploma } \\
\text { training programs are selected }\end{array}$ & 3.99 & 1.017 \\
\hline $\begin{array}{l}\text { 2. The trainers whose experience is consistent with the nature of the diploma } \\
\text { training programs are selected }\end{array}$ & 3.98 & 1.009 \\
\hline $\begin{array}{l}\text { 3. The trainers whose major is consistent with the nature of the diploma } \\
\text { training program are selected }\end{array}$ & 3.91 & 1.001 \\
\hline $\begin{array}{l}\text { 4. The selected trainers are the ones who possess expertise that enables them } \\
\text { to change the trainees' behavioral attitudes and encourage them to improve } \\
\text { performance }\end{array}$ & 3.96 & 1.028 \\
\hline Assessment of training programs & & \\
\hline $\begin{array}{l}\text { 1. A comparison is conducted between the pre-training performance and the } \\
\text { after-training performance }\end{array}$ & 3.74 & 1.006 \\
\hline $\begin{array}{l}\text { 2. The trainee is assessed immediately after finishing the training diploma } \\
\text { program }\end{array}$ & 3.73 & .934 \\
\hline
\end{tabular}




\begin{tabular}{lll}
\hline 3. The training efficiency and effectiveness are assessed & 3.76 & .947 \\
4. The quality of the training programs and the diploma training programs is & 3.69 & .942 \\
connected to the goals of the business organization & & .862 \\
5. The diploma training program and their subjects are consistent with the & 3.74 & \\
nature of the activity carried out by the business organization & & .917 \\
Performance of trainees & 4.00 & .952 \\
1. The performance level is improved & 3.82 & .953 \\
2. The extent of wasting time at work decreased & 3.93 & .934 \\
3. The mistakes at work decreased & 3.95 & .993 \\
4. The trainee's productivity level increased & 3.82 & \\
5. The injuries at the workplace decreased & &
\end{tabular}

The researcher of the present study also calculated the average of the five rating points of the adopted scale which is 3 . Based on the table above, it can be noticed that the respondents have positive attitudes. That's because the overall attitude (3.82) is greater than the average of the five rating points (3). The means are within the range of (3.44-4.03). That indicates that respondents have positive attitudes.

\subsection{The Instrument's Reliability}

In order to measure the instrument's reliability, the researcher calculated the value of the Cronbach alpha coefficient. It was found that the percentage of the Cronbach alpha coefficient is $97 \%$. It's considered as an excellent value because it's greater than $60 \%$.

\subsection{Testing the Study's Hypotheses}

1)- The partnership between the Public Authority for Applied Education and Training and the Kuwaiti labor market has an impact on the outcome quality of the training sector in Kuwait

Table 3. Testing the first hypothesis

\begin{tabular}{lllll}
\hline $\begin{array}{l}\text { Model Summary } \\
\text { Model }\end{array}$ & R & R Square & Adjusted R Square & $\begin{array}{l}\text { Std. Error of the } \\
\text { Estimate }\end{array}$ \\
\hline 1 & .799 & .638 & .627 & .52626 \\
\hline
\end{tabular}

\begin{tabular}{|c|c|c|c|c|c|c|}
\hline \multicolumn{7}{|c|}{ ANOVA } \\
\hline Model & & Sum of Squares & df & Mean Square & $\mathrm{F}$ & Sig. \\
\hline & Regression & 98.537 & 6 & 16.423 & 59.299 & $.000^{\mathrm{b}}$ \\
\hline \multirow[t]{2}{*}{1} & Residual & 55.944 & 202 & .277 & & \\
\hline & Total & 154.482 & 208 & & & \\
\hline \multicolumn{7}{|c|}{ Coefficients } \\
\hline \multirow[t]{3}{*}{ Model } & & \multirow{2}{*}{\multicolumn{2}{|c|}{ Unstandardized Coefficients }} & Standardized & $\mathrm{t}$ & Sig. \\
\hline & & & & Coefficients & & \\
\hline & & $\mathrm{B}$ & Std. Error & Beta & & \\
\hline \multirow{7}{*}{1} & (Constant) & .425 & .196 & & 2.169 & .031 \\
\hline & ind1 & .132 & .075 & .123 & 1.749 & .082 \\
\hline & ind 2 & .113 & .070 & .121 & 1.620 & .107 \\
\hline & ind 3 & .116 & .077 & .113 & 1.497 & .136 \\
\hline & ind4 & -.055 & .068 & -.057 & -.816 & .415 \\
\hline & ind5 & .116 & .063 & .128 & 1.840 & .067 \\
\hline & ind6 & .495 & .070 & .474 & 7.113 & .000 \\
\hline
\end{tabular}

The multiple regression analysis was conducted to test the first hypothesis. It was found that the calculated $\mathrm{F}$ value is 59.299 which is statistically significant at the statistical significance level of a $=0.05$. It was found that the partnership between the Public Authority for Applied Education and Training and the Kuwaiti labor market has an impact on the outcome quality of the training sector in Kuwait. The correlation coefficient value is 0.799 . $63.8 \%$ of the change in the dependent variable is attributed to the independent variable. 
Ha.2)- The process of identifying the training needs has an impact on the trainees' performance in Kuwait.

Table 4. Testing the second hypothesis

\begin{tabular}{|c|c|c|c|c|c|c|}
\hline \multicolumn{7}{|c|}{ Model Summary } \\
\hline Model & $\mathrm{R}$ & R Square & ed R Square & \multicolumn{3}{|l|}{ Estimate } \\
\hline$\underline{1}$ & .639 & .409 & & .66428 & & \\
\hline \multicolumn{7}{|c|}{ ANOVA } \\
\hline \multirow[t]{2}{*}{ Model } & & Sum of Squares & df & Mean Square & $\mathrm{F}$ & Sig. \\
\hline & Regression & 63.140 & 1 & 63.140 & 143.089 & .000 \\
\hline \multirow[t]{2}{*}{1} & Residual & 91.342 & 207 & .441 & & \\
\hline & Total & 154.482 & 208 & & & \\
\hline \multicolumn{7}{|c|}{ Coefficients } \\
\hline \multirow[t]{3}{*}{ Model } & & \multirow{2}{*}{\multicolumn{2}{|c|}{ Unstandardized Coefficients }} & Standardized & $\mathrm{T}$ & Sig. \\
\hline & & & & Coefficients & & \\
\hline & & $\mathrm{B}$ & d. Error & Beta & & \\
\hline & (Constant) & 1.381 & 16 & & 6.390 & .000 \\
\hline & ind 1 & .683 & 57 & .639 & 11.962 & .000 \\
\hline
\end{tabular}

The simple multiple regression analysis was conducted to test the second hypothesis. It was found that the calculated $\mathrm{F}$ value is 143.089 which is statistically significant at the statistical significance level of $\mathrm{a}=0.05$. The process of identifying the training needs has a statistically significant impact on the trainees' performance in Kuwait. The correlation coefficient value is $0.639 .40 .9 \%$ of the change in the dependent variable is attributed to the independent variable.

Ha.3)- The process of designing the training programs and diploma training programs has an impact on the trainees' performance in Kuwait

Table 5. Testing the third hypothesis

\begin{tabular}{|c|c|c|c|c|c|c|}
\hline \multicolumn{7}{|c|}{ Model Summary } \\
\hline \multirow[t]{2}{*}{ Model } & \multirow[t]{2}{*}{$\mathrm{R}$} & \multirow[t]{2}{*}{ R Square } & \multirow[t]{2}{*}{ Adjusted R Square } & \multirow{2}{*}{\multicolumn{3}{|c|}{$\begin{array}{l}\text { Std. Error of the } \\
\text { Estimate }\end{array}$}} \\
\hline & & & & & & \\
\hline 1 & .660 & .436 & 433 & .64871 & & \\
\hline \multicolumn{7}{|c|}{ ANOVA } \\
\hline \multicolumn{2}{|c|}{ Model } & Sum of Squares & $\mathrm{df}$ & Mean Square & $\mathrm{F}$ & Sig. \\
\hline \multirow{3}{*}{1} & Regression & 67.371 & 1 & 67.371 & 160.093 & .000 \\
\hline & Residual & 87.111 & 207 & .421 & & \\
\hline & Total & 154.482 & 208 & & & \\
\hline
\end{tabular}

\begin{tabular}{|c|c|c|c|c|c|c|}
\hline \multicolumn{7}{|c|}{ Coefficients } \\
\hline \multirow[t]{2}{*}{ Model } & & \multicolumn{2}{|c|}{ Unstandardized Coefficients } & Standardized & $\mathrm{T}$ & Sig. \\
\hline & & B & Std. Error & Beta & & \\
\hline \multirow{2}{*}{1} & (Constant) & 1.572 & .190 & & 8.278 & .000 \\
\hline & ind 2 & .620 & .049 & .660 & 12.653 & .000 \\
\hline
\end{tabular}

The simple multiple regression analysis was conducted to test the third hypothesis. It was found that the calculated $F$ value is 160.093 which is statistically significant at the statistical significance level of $a=0.05$. It was found that the process of designing the training programs and diploma training programs has a statistically significant impact on the trainees' performance in Kuwait. The correlation coefficient value is $0.66 .43 .6 \%$ of the change in the dependent variable is attributed to the independent variable. 
Ha.4)- The process of implementing the training programs and diploma training programs has an impact on the trainees' performance in Kuwait

Table 5. Testing the fourth hypothesis

\begin{tabular}{lllll}
\multicolumn{2}{l}{ Model Summary } \\
\hline Model & $\mathrm{R}$ & R Square & Adjusted R Square & $\begin{array}{l}\text { Std. Error of the } \\
\text { Estimate }\end{array}$ \\
\hline 1 & .653 & .427 & .424 & .65407 \\
\hline
\end{tabular}

\begin{tabular}{|c|c|c|c|c|c|c|}
\hline \multicolumn{7}{|c|}{ ANOVA } \\
\hline Model & & Sum of Squares & $\mathrm{df}$ & Mean Square & $\mathrm{F}$ & Sig. \\
\hline \multirow{3}{*}{1} & Regression & 65.926 & 1 & 65.926 & 154.102 & .000 \\
\hline & Residual & 88.556 & 207 & .428 & & \\
\hline & Total & 154.482 & 208 & & & \\
\hline
\end{tabular}

\begin{tabular}{|c|c|c|c|c|c|c|}
\hline \multicolumn{7}{|c|}{ Coefficients } \\
\hline \multirow[t]{2}{*}{ Model } & & \multicolumn{2}{|c|}{ Unstandardized Coefficients } & \multirow{2}{*}{$\begin{array}{l}\text { Standardized } \\
\text { Coefficients } \\
\text { Beta }\end{array}$} & \multirow[t]{2}{*}{$\mathrm{t}$} & \multirow[t]{2}{*}{ Sig. } \\
\hline & & $\mathrm{B}$ & Std. Error & & & \\
\hline \multirow{2}{*}{1} & (Constant) & 1.250 & .219 & & 5.713 & .000 \\
\hline & ind3 & .673 & .054 & .653 & 12.414 & .000 \\
\hline
\end{tabular}

The simple multiple regression analysis was conducted to test the fourth hypothesis. It was found that the calculated $F$ value is 154.102 which is statistically significant at the statistical significance level of $a=0.05$. It was found that the process of implementing the training programs and diploma training programs has a statistically significant impact on the trainees' performance in Kuwait. The correlation coefficient value is 0.653. $42.7 \%$ of the change in the dependent variable is attributed to the independent variable.

Ha.5)-The process of selecting the trainees has an impact on the trainees' performance in Kuwait

Table 6. Testing the fifth hypothesis

\begin{tabular}{lllll} 
Model Summary & & & \\
\hline Model & $\mathrm{R}$ & R Square & Adjusted R Square & $\begin{array}{l}\text { Std. Error of the } \\
\text { Estimate }\end{array}$ \\
\hline 1 & .586 & .343 & .340 & .70023
\end{tabular}

\begin{tabular}{|c|c|c|c|c|c|c|}
\hline \multicolumn{7}{|c|}{ ANOVA } \\
\hline Model & & Sum of Squares & df & Mean Square & $\mathrm{F}$ & Sig. \\
\hline \multirow{3}{*}{1} & Regression & 52.987 & 1 & 52.987 & 108.066 & .000 \\
\hline & Residual & 101.495 & 207 & .490 & & \\
\hline & Total & 154.482 & 208 & & & \\
\hline \multicolumn{7}{|c|}{ Coefficients } \\
\hline \multirow[t]{3}{*}{ Model } & & \multirow{2}{*}{\multicolumn{2}{|c|}{ Unstandardized Coefficients }} & Standardized & $\mathrm{t}$ & Sig. \\
\hline & & & & Coefficients & & \\
\hline & & $\mathrm{B}$ & Std. Error & Beta & & \\
\hline \multirow{2}{*}{1} & (Constant) & 1.886 & .200 & & 9.415 & .000 \\
\hline & ind4 & .571 & .055 & .586 & 10.395 & .000 \\
\hline
\end{tabular}

The simple multiple regression analysis was conducted to test the fifth hypothesis. It was found that the calculated $\mathrm{F}$ value is 108.066 which is statistically significant at the statistical significance level of $\mathrm{a}=0.05$. It was found that the process of selecting the trainees has a statistically significant impact on the trainees' performance in Kuwait. The correlation coefficient value is $0.586 .34 .3 \%$ of the change in the dependent 
variable is attributed to the independent variable.

Ha.6)- The process of selecting the trainers has an impact on the trainees' performance in Kuwait

Table 7. Testing the sixth hypothesis

\begin{tabular}{|c|c|c|c|c|}
\hline \multicolumn{5}{|c|}{ Model Summary } \\
\hline Model & $\mathrm{R}$ & R Square & Adjusted R Square & $\begin{array}{l}\text { Std. Error of the } \\
\text { Estimate }\end{array}$ \\
\hline 1 & .615 & .378 & .375 & .68118 \\
\hline
\end{tabular}

\begin{tabular}{|c|c|c|c|c|c|c|}
\hline \multicolumn{7}{|c|}{ ANOVA } \\
\hline Model & & Sum of Squares & $\mathrm{df}$ & Mean Square & $\mathrm{F}$ & Sig. \\
\hline \multirow{3}{*}{1} & Regression & 58.432 & 1 & 58.432 & 125.928 & .000 \\
\hline & Residual & 96.050 & 207 & .464 & & \\
\hline & Total & 154.482 & 208 & & & \\
\hline \multicolumn{7}{|c|}{ Coefficients } \\
\hline \multirow[t]{3}{*}{ Model } & & \multirow{2}{*}{\multicolumn{2}{|c|}{ Unstandardized Coefficients }} & Standardized & $\mathrm{t}$ & Sig. \\
\hline & & & & Coefficients & & \\
\hline & & $\mathrm{B}$ & Std. Error & Beta & & \\
\hline \multirow{2}{*}{1} & (Constant) & 1.700 & .202 & & 8.405 & .000 \\
\hline & ind5 & .557 & .050 & .615 & 11.222 & .000 \\
\hline
\end{tabular}

The simple multiple regression analysis was conducted to test the sixth hypothesis. It was found that the calculated $\mathrm{F}$ value is 125.928 which is statistically significant at the statistical significance level of $\mathrm{a}=0.05$. It was found that the process of selecting the trainers has a statistically significant impact on the trainees' performance in Kuwait. The correlation coefficient value is $0.615 .37 .8 \%$ of the change in the dependent variable is attributed to the independent variable.

Ha.7)- The process of evaluating the training programs has an impact on the trainees' performance in Kuwait

Table 8. Testing the seventh hypothesis

\begin{tabular}{llllll}
\multicolumn{2}{l}{$\begin{array}{l}\text { Model Summary } \\
\text { Model }\end{array}$} & R & R Square & Adjusted R Square & $\begin{array}{l}\text { Std. Error of the } \\
\text { Estimate }\end{array}$ \\
\hline 1 & .759 & .576 & .574 & .56230 & \\
\hline
\end{tabular}

\begin{tabular}{|c|c|c|c|c|c|c|}
\hline \multicolumn{7}{|c|}{ ANOVA } \\
\hline Model & & Sum of Squares & df & Mean Square & $\mathrm{F}$ & Sig. \\
\hline \multirow{3}{*}{1} & Regression & 89.031 & 1 & 89.031 & 281.579 & .000 \\
\hline & Residual & 65.451 & 207 & .316 & & \\
\hline & Total & 154.482 & 208 & & & \\
\hline \multicolumn{7}{|c|}{ Coefficients } \\
\hline \multirow[t]{3}{*}{ Model } & & \multirow{2}{*}{\multicolumn{2}{|c|}{ Unstandardized Coefficients }} & Standardized & $\mathrm{t}$ & Sig. \\
\hline & & & & Coefficients & & \\
\hline & & $\mathrm{B}$ & Std. Error & Beta & & \\
\hline \multirow{2}{*}{1} & (Constant) & .952 & .180 & & 5.283 & .000 \\
\hline & ind6 & .792 & .047 & .759 & 16.780 & .000 \\
\hline
\end{tabular}

The simple multiple regression analysis was conducted to test the seventh hypothesis. It was found that the calculated $F$ value is 281.579 which is statistically significant at the statistical significance level of $a=0.05$. It was found that the process of evaluating the training programs has an impact on the trainees' performance in 
Kuwait. The correlation coefficient value is $0.759 .57 .6 \%$ of the change in the dependent variable is attributed to the independent variable.

\section{Results}

The researcher concluded the following:

1. The partnership between the Public Authority for Applied Education and Training and the Kuwaiti labor market has an impact on the outcome quality of the training sector in Kuwait

2. The process of identifying the training needs has an impact on the trainees' performance in Kuwait

3. The process of designing the training programs and diploma training programs has an impact on the trainees' performance in Kuwait

4. The process of implementing the training programs and diploma training programs has an impact on the trainees' performance in Kuwait

5. The process of selecting the trainees has an impact on the trainees' performance in Kuwait

6. The process of selecting the trainers has an impact on the trainees' performance in Kuwait

7. The process of evaluating the training programs has an impact on the trainees' performance in Kuwait

In the light of the aforementioned results, it can be concluded that the Public Authority for Applied Education and Training provides much attention to training. It can be concluded that the process of evaluating the training programs has the strongest impact on the trainees' performance in Kuwait.

The researcher found that the partnership between the Public Authority for Applied Education and Training and the Kuwaiti labor market is considered very significant. The results of the present study are in agreement with the results that were concluded by (Wei-Tao, 2006) (Marcel, et.al, 2002) (Gauld \& Miller, 2004) and Nivorozhkin (2005).

\section{Recommendations}

\section{The researcher recommends the following:}

1. Activating the role of the partnership between the Public Authority for Applied Education and Training and the Kuwaiti labor market

2. Choosing the ones enrolled in the diploma training programs based on their personal desires and interests

3. Using modern and advanced methods that are consistent with the nature of work at ministries

4. Choosing trainers whose major is consistent with the nature of the diploma training program

5. Connecting the quality of the training programs and the diploma training programs with the goals of the business organization

6. Designing training programs and the diploma training programs for solving work-related problems at public institutions.

7. Identifying the training needs based on the tests held at the relevant ministries.

8. Identifying the training needs through reviewing the opinions of administrators in various administrative levels at ministries and public bodies

9. Conducting similar studies that shed a light on other aspects of the Public Authority for Applied Education and Training.

\section{References}

Abed Al-Fattah, M. (2013). The theory of training: Shifting from training principles and ideas into a reality. Cairo: The Arab Group for training and publication.

Ahmed, A., \& Ramzan, M. (2013). Effects of Job Stress on Employees Job Performance A Study on Banking Sector of Pakistan. Journal of Business and Management (IOSR-JBM), 11(6), 61-68. https://doi.org/10.9790/487X-1166168

Aldulaimi, S. H. (2016). Fundamental Islamic perspective of work ethics. Journal of Islamic Accounting and Business Research, 7(1), 59-76. https://doi.org/10.1108/JIABR-02-2014-0006

Al-Janabi, A. (2009). The impact of training on raising productivity at work: A field study in the Jordanian industrial joint-stock companies. Unpublished MA thesis. Al- Balqa' applied university. Jordan 
Al-Khafaji, I. (2016). Employ benchmarking to Appraisal the performance of employees in achieving the total quality of human resources requirements - applied research in the Office of the Inspector General / Martyrs Foundation. Prof. Abed Al-Naser Alak Hafez/ Assistant general-manager at the studies department. Ministry of Higher Education and Scientific Research. Journal of Economics and Administrative Sciences.

Celine, F. (2018). Effects of Job - Stress on Employee Performance in an Enterprise: A microfinance institution in Cameroon. Master Thesis, Centria University of Applied Sciences.

Gauld, D., \& Miller, P. (2004). The qualifications and competencies held by effective workplace trainers. Journal of European Industrial Training, 28(1), 8-22. https://doi.org/10.1108/03090590410513866

Gomez- Mejia, L. R. , Balkin, D. B., \& Cardy, R. L. (2001). Managing Human Resources (3rd ed.). New Jersey.

Guan, X., \& Frenkel, S. (2018). How HR practice, work engagement and job crafting influence employee performance. Chinese Management Studies, 12(3), 591-607. https://doi.org/10.1108/CMS-11-2017-0328

Hasu, M., Honkaniemi, L., Saari, E., Mattelmäki, T., \& Koponen, L. (2014). Learning employee-driven innovating: Towards sustained practice through multi-method evaluation. Journal of Workplace Learning, 26(5), 310-330. https://doi.org/10.1108/JWL-10-2013-0079

Jacqueline, R., \& Maria, V. (2006). What role can training needs play in Organizational Change (pp. 393-407). https://doi.org/10.1108/09534810610668382

Jill, B., \& John, P. W. (2008). Different roles, difference Perspectives: Perceptions about the purpose of Training needs analysis. Industrial and Commercial Training, 40(1), 38-41. https://doi.org/10.1108/00197850810841639

Lawson, K. S., \& Alan, L. J. (2004). Does training influence outcomes of organizations? Some Australian evidence. Journal of Management Development, 23(2), 119-123. https://doi.org/10.1108/02621710410517210

Marcel, R., Van der, K., \& Jan, N. S. (2002). Effectiveness of on the job training. Journal of European Industrial Training, 26(2/3/4), 196-199. https://doi.org/10.1108/03090590210422076

Mohammad, J., \& Quoquab, F. (2016). Furthering the thought on Islamic work ethic: how does it differ? Journal of Islamic Marketing, 7(3), 355-375. https://doi.org/10.1108/JIMA-07-2014-0047

Nassazi, A. (2013). Effects of Training on employee performance: evidence from Uganda. Thesis, University of Applied Sciences.

Nazir, O., \& Islam, J. U. (2017). Enhancing organizational commitment and employee performance through employee engagement: An empirical check. South Asian Journal of Business Studies, 6(1), 98-114. https://doi.org/10.1108/SAJBS-04-2016-0036

Nivorozhkin, A. (2005). An evaluation of government- sponsored vocational training programmes for the unemployed in urban Russia. Cambridge Journal of Economics, 29(6), 1053-1072. https://doi.org/10.1093/cje/bei087

Redwan, M. A. A. F. (2012). Designing, implementing and assessing training programs. Cairo: The Arab Group for training and publication.

Sanda, M. A., \& Kuada, J. (2016). Influencing dynamics of culture and employee factors on retail banks' performances in a developing country context. Management Research Review, 39(5), 599-628. https://doi.org/10.1108/MRR-04-2015-0078

Scott, K. L., \& Duffy, M. K. (2015). Antecedents of workplace ostracism: New directions in research and intervention. In Mistreatment in Organizations (pp. 137-165). Emerald Group Publishing Limited. https://doi.org/10.1108/S1479-355520150000013005

Swart, J., Mann, C., Brown, S., \& Price, A. (2005). Human resource development: strategy and tactics. Oxford: Elsevier Butterworth- Heinemann Publications.

Wei-Tao, T. (2006). Effects of training framing, general self-efficacy and training motivation on trainees training effectiveness. Conference: Human Resources Development Conference on the Challenging of Human, 35. https://doi.org/10.1108/00483480610636786

White, M., \& Mackenzie-Davey, K. (2003). Feeling valued at work? A qualitative study of corporate training consultants. Career Development International, 8(5), 228-34. https://doi.org/10.1108/13620430310497395 
Wright, T. A., \& Bonett, D. G. (2007). Job satisfaction and psychological Well-being as nonadditive Predictors of Workplace Turnover. Journal of Management, 33(2), 141-160. https://doi.org/10.1177/0149206306297582

Young, N. (2009). Understanding the research process and methods: an introduction to research methods. Las Vegas: Act Press.

\section{Copyrights}

Copyright for this article is retained by the author(s), with first publication rights granted to the journal.

This is an open-access article distributed under the terms and conditions of the Creative Commons Attribution license (http://creativecommons.org/licenses/by/4.0/). 